\title{
A comparison of package and nucleus production from honey bee (Apis mellifera L.) colonies
}

\author{
E.N. Punnett and M.L. Winston \\ Simon Fraser University, Departement of Biological Sciences, Burnaby, B.C. V5A 1 S6 Canada
}

(received 3 August 1988, accepted 16 August 1989)

\begin{abstract}
Summary - In April, various combinations of packages and/or nuclei were removed from colonies to determine the biological and economic impact of package and/or nucleus production on these colonies. All colonies used for bee production yielded greater economic returns than the control colonies from which no packages or nuclei were removed. In addition, the colonies used for package and/or nucleus production did not differ significantly from the control colonies by the end of the season in nearly all of the biological characteristics monitored. The results indicate that both package and nucleus production is feasible in the Lower Fraser Valley area of $\mathrm{BC}$, and would provide local beekeepers with additional income.
\end{abstract}

beekeeping - package production — nucleus production — economic impact — Canada

\section{INTRODUCTION}

Present management systems leave Canadian beekeepers dependent upon package bee and queen importations from the southern United States each spring. In $1984,323,000$ packages, worth $\$ 7.4$ million (Canadian dollars) were imported into Canada (Statistics Canada 1984). Restrictions on the importation of bees from the US began with the discovery of the mite Acarapis woodi in the US in 1984. A complete ban on importations was imposed in 1987 due to another mite, Varroa jacobso- ni, and future limits on importations are expected, due to the Africanized honey bee, which is rapidly expanding its ranges, northward from South and Central America (reviewed by Winston 1983). Thus, a local bee production industry would not only be a new and lucrative source of income to local beekeepers, but may be essential to the survival of Canadian beekeeping (Scott \& Winston, 1985; Winston, 1986).

There are two commercial types of bee production; packages and nuclei. To produce packages, a portion of the worker 
population is removed from the colony, whereas, nucleus production involves the removal of combs containing brood, honey and pollen in addition to a portion of the worker population. The comparative biological and economic impact of package versus nuclei removal has not been investigated. Nucleus removal may lower the biological performance of a colony, yet be economically feasible due to the higher sale price. The objective of this research was to compare various combinations of package and nucleus production in April. Colonies were monitored through the season following the removal of packages and nuclei to determine the biological and economic impact of package and/or nucleus production.

\section{MATERIAL AND METHODS}

This study was conducted from September 1983 to August 1984 in the Lower Fraser Valley area of southwestern Bristish Columbia, using three apiary sites located in Langley. A total of 56 colonies, each in two standard deep Langstroth hive bodies, were divided evenly among the three apiary sites and requeened in September with Italian (Apis mellifera ligustica L.) queens reared from BC Ministry of Agriculture and Food stock. The dimensions of all standard Langstroth hive bodies used were $497 \mathrm{~mm} \times$ $420 \mathrm{~mm} \times 241 \mathrm{~mm}$ deep. During September and early October, all colonies were fed sugar syrup with oxytetracycline hydrochloride and fumagillin antibiotics to provide sufficient winter stores, as well as, for the prevention of disease. Frames of brood, honey and pollen were transferred between colonies so that by mid-October all colonies were of approximately equal size. Between 13 February and 16 April all colonies were fed a total of $1,550 \mathrm{~g}$ of brewers yeastbased pollen supplement to stimulate brood rearing, as well as, $13.5 \mathrm{~L}$ of sugar syrup, containing oxytetracycline hydrochloride and fumagillin antibiotics. Frames of brood, honey and pollen were again transferred between colonies in early April (before package and nucleus removal) to equalize colonies. Between 21 May and 8 June, when floral nectar was not available, $9.0 \mathrm{~L}$ of sugar syrup was fed to all colonies in order to prevent starvation. Oxytetracycline hydrochloride, mixed in icing sugar, was fed from 5 April to 30 June for brood disease prevention. All colonies were managed for honey production throughout the season using standard techniques. One or two standard Langstroth supers were added to colonies as required for honey storage.

The 56 colonies were randomly divided between seven treatments, with eight colonies per treatment being divided as evenly as possible among the three sites. The seven treatments were :

1. Control; no packages or nuclei removed.

2. 2-Packages; two packages removed on 16 April.

3. 3-Packages; two packages removed on 16 April and one package removed on 1 May.

\section{2-Nuclei; two nuclei removed on 16 April.}

5. 3-Nuclei; two nuclei removed on 16 April and one nucleus removed on 1 May.

6. 1-Packages/1-Nucleus; one package and one nucleus removed on 16 April.

7. 2-Packages/1-Nucleus; one package and one nucleus removed on 16 April, and one package removed on 1 May.

To shake packages, frames containing workers were shaken into a funnel which rested on a screened package cage, which in turn rested on a scale used to determine when the proper weight of workers had been removed from each colony. A queen was added when $0.9 \mathrm{~kg}$ of workers were in the package. The nuclei were established by placing three frames of brood (mainly sealed brood), one frame of honey and pollen, and the equivalent of four full frames of workers into a cardboard nucleus box into which a queen was added. The packages and nuclei were not used again for this experiment.

Colony characteristics were monitored at approximately 21- day intervals from April until the honey was harvested in August. Five dates were chosen to describe the colony characteristics : before packages and/or nuclei were removed (8 April); after the first set of packages and/or nuclei were removed (25 April); after the second set of packages and/or nuclei were re- 
moved (18 May); mid-season (1 July); and at the end of the season (11 August). The colony characteristics monitored were sealed brood, honey, and pollen areas, colony weight, and frames of bees. Sealed brood, honey and pollen areas were measured using a plexiglass grid to estimate the area of each frame. All colonies were weighed with a tripod scale. Colony weight was determined by subtracting the weight of empty equipment from the tripod scale reading. The number of frames of adult workers was estimated by looking through the supers from above and below to determine how many frames were covered by workers. Extracted honey was determined by weighing supers before and after frames of honey were extracted. All colonies were left with the equivalent of 6 full frames of honey after honey removal in August.

Cost breakdowns used in determining income per colony were as follows :

1. Honey Income :

Mean honey yield $\mathrm{x}$ price $\mathrm{kg}=$ honey income

Honey was valued at $\$ 1.12$ per $\mathrm{kg}$ for bulk sales, the average BC price in 1984. Production costs have not been included in the calculation of honey income.

2. Package Income :

$\$ 29.70 /$ package - (Production costs of \$22.45) $=\$ 7.25$

3. Nucleus Income :

$\$ 35.00 / 4$-frame nucleus - (production costs of $\$ 20.10)=\$ 14.90$

It was assumed that the purchaser of the nucleus would provide the nucleus box, as well as, four replacement frames to the producer.

All figures used for economic analyses were obtained from the British Columbia Ministry of Agriculture and Food annual report (McCutcheon, 1984a) and preliminary economic analysis of package production (Anonymous, 1983), and are expressed in Canadian dollars.

Data were analyzed using ANOVA, followed by Duncan's multiple range test to compare means when $F$ values were significant ( $P \leq 0.05)$.

\section{RESULTS}

None of the biological characteristics differed significantly on the first and last measurement dates, 8 April (before package and/or nucleus removal) and $11 \mathrm{Au}$ gust (end of the season) (Fig. 1) (PO0.05), except for frames of bees, where treatment 5 (3 nuclei removed) was significantly lower than all other treatments except treatment 3 ( 3 packages removed) on $11 \mathrm{Au}$ gust $(P=0.03)$ (Fig. 1). Biological characteristics differed significantly between various treatments on the three other measurement dates (Fig. 1) ( $P \leq 0.05)$. Generally, the treatments from which nuclei were removed (treatments 4 through 7) were significantly lower than the control and package treatments (treatments 1,2 and 3 ), with treatments 4 (2 nuclei removed), and particularly 5 ( 3 nuclei removed), being the lowest of all. Extracted honey was not significantly different between any of the treatments $(P=0.09)$ (Table I). However, treatment 5 ( 3 nuclei removed) produced only $10.4 \mathrm{~kg}$ extracted honey, compared to 24.1 to $28.2 \mathrm{~kg}$ for the remaining treatments.

All treatments from which packages and/or nuclei were removed provided greater economic returns ( $\$ 45.97-\$ 60.98$ ), than the control colonies used of solely for honey production (\$28.90) (Table I). The 4 treatments which involved nuclei production (treatments 4 through 7) provided the highest profits $(\$ 53.40-\$ 60.98)$, followed by the 2 and 3 package treatments ( $\$ 45.97$ and $\$ 48.74$, respectively) (Table I).

\section{DISCUSSION}

These results demonstrate that spring production of both packages and nuclei in the Lower Fraser Valley area of Britisch Columbia is both biologically feasible and yields a higher income than honey production alone. 
Table I. Incomes from packages and/or nucleus production systems.

\begin{tabular}{lcccccc}
\hline Treatment & $\begin{array}{c}\text { Package } \\
\text { income } \\
(\$)\end{array}$ & $\begin{array}{c}\text { Nucleus } \\
\text { income } \\
(\$)\end{array}$ & $\begin{array}{c}\text { Extracted } \\
\text { honey } \\
(\mathrm{kg})\end{array}$ & $\begin{array}{c}\text { Honey } \\
\text { income } \\
(\$)\end{array}$ & $\begin{array}{c}\text { Total } \\
\text { income } \\
(\$)\end{array}$ & $\begin{array}{c}\text { Economic } \\
\text { ranking }\end{array}$ \\
\hline Control & - & - & 25.8 & 28.90 & 28.90 & 7 \\
2P & 14.50 & - & 28.1 & 31.47 & 45.97 & 6 \\
3P & 21.75 & - & 24.1 & 26.99 & 48.74 & 5 \\
2N & - & 29.80 & 26.8 & 30.02 & 59.82 & 2 \\
$3 N$ & - & 44.70 & 10.4 & 11.65 & 56.35 & 3 \\
$1 P / 1 N$ & 7.25 & 14.90 & 27.9 & 31.25 & 53.40 & 4 \\
$2 \mathrm{P} / 1 \mathrm{~N}$ & 14.50 & 14.90 & 28.2 & 31.58 & 60.98 & 1 \\
\hline
\end{tabular}

On 25 April (11 days after the first package and/or nucleus removal) and 18 May (20 days after the second package and/or nucleus removal), various significant differences in biological characteristics were recorded between the treatments (Fig. 1). Generally, the treatments from which nuclei were removed (treatments 4 through 7) were significantly lower than the control and package-only treatments (treatments 1,2 and 3 ), with the 2 and 3 nucleus production colonies (treatments 4 and 5) being the lowest of all. This trend can be attributed to the fact that these colonies had brood, honey, pollen and a larger portion of the worker population removed, compared to the package-only treatments. By 1 July (2 months after nucleus removal), all treatments were equivalent except for treatment 5 (3 nuclei removed), which was still significantly lower than almost all other treatments for all biological characteristics except sealed brood (Fig. 1). This indicates that colonies given the 3-nuclei treatment were allotting a high proportion of their available resources to brood rearing, leaving a relatively small proportion of the population available for foraging. This resulted in significantly lower honey and pollen areas and lower extracted honey yields than any other treatment (Fig. 1). This explanation is supported by Farrar (1968), who reported that smaller colonies put a higher proportion of available resources into brood rearing, as compared to larger colonies, leaving a smaller foraging force, which in turn produces lower honey yields.

By 11 August, the colonies from which packages and/or nuclei were removed (treatments 2 through 7) did not differ significantly from the control colonies (treatment 1) in almost all of the biological characteristics. This is a remarkable result considering the amount of brood and workers removed in April. Changes in age specific division of labor following package shaking or nucleus removal may be one mechanism responsible for this "rebound effect" (Winston \& Mitchell, 1986; Winston et al., 1985). Winston and Fergusson (1985) found that workers emerging in colonies after two or three packages were shaken in April, began foraging at earlier ages and had shorter life spans than those in control colonies, suggesting that shifts in temporal caste structure can compensate for worker loss. This concept is based on observations from numerous studies (reviewed by Winston, 1987 and Winston \& Fergusson, 1985) showing that under nonstressed conditions, honey bee workers are lethargic and spend much of their time standing in the hive. Colonies, therefore, 


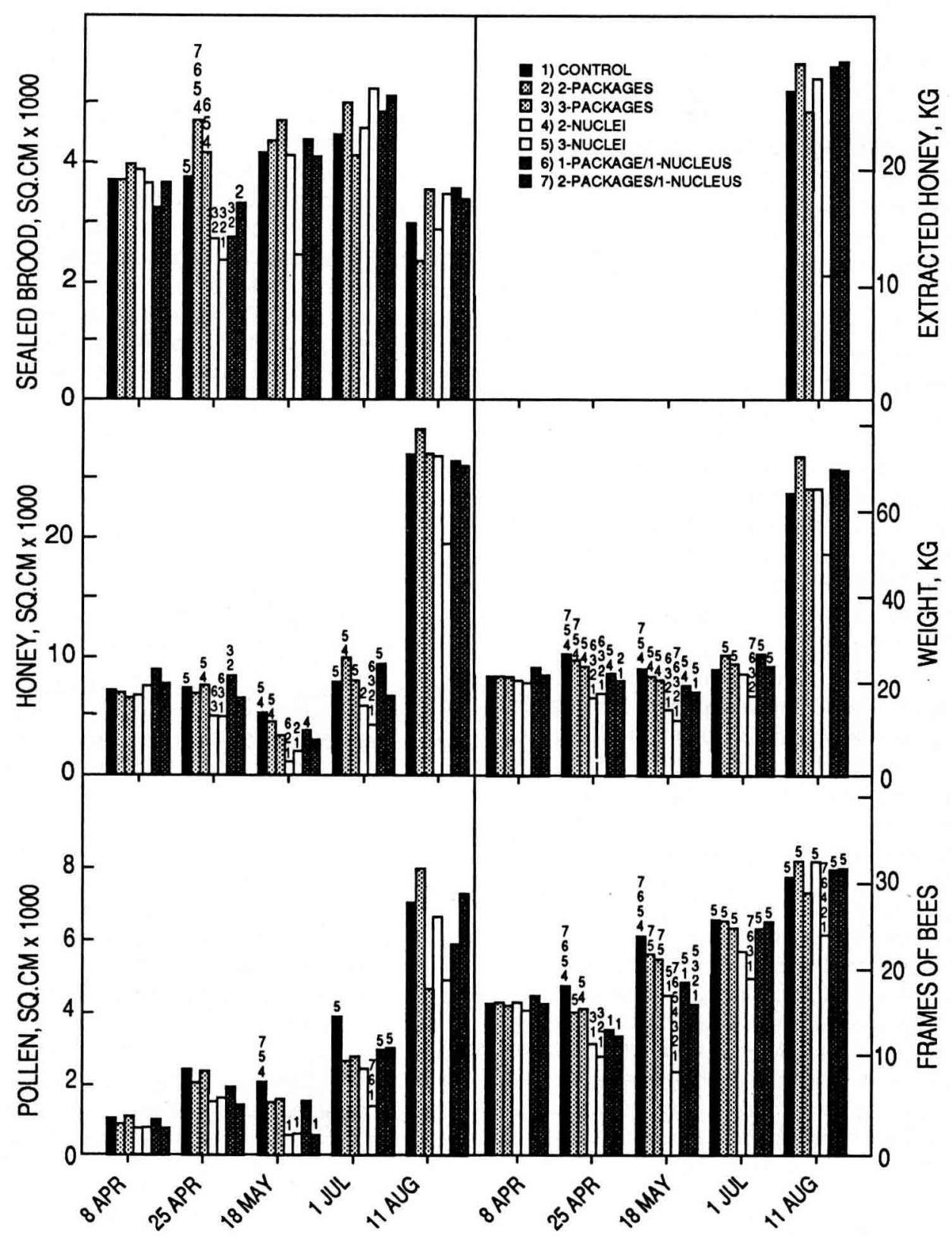

Fig. 1. Biological (sealed brood, honey and pollen areas, frames of bees and colony weight) and economic (extracted honey) characteristics on five measurement dates for seven treatments. Numbers above each treatment indicate significant differences between that treatment and the treatment indicated by the number ( $P \leq 0.05$ ); no number above the histogram for a measurement date indicates that there were no significant differences between treatments ( $>0.05)$. 
have a reserve force that can respond to both natural (swarming, predation, disease or sudden weather changes) and management (package and nucleus removal) population loss by accelerating their division of labour schedule so that tasks such as foraging are initiated at earlier stages. More research is required on age-specific division of labour in stressed colonies to fully understand this "rebound effect".

Treatment 5 (3 nuclei removed) did not rebound as quickly as the other treatments, perhaps due to the severity of the removal of bees and brood. Treatment 4 (2 nuclei removed) produced as much honey as the control, whereas, treatment 5 ( 3 nuclei removed) had lower honey production, indicating an upper limit to the number of nuclei which can be removed without causing a reduction in colony performance

Colonies from which packages and/or nuclei were removed provided higher income than control colonies, and colonies from which nuclei were removed showed the highest income (Table I). Treatments involving nuclei (except 3 nuclei, treatment 5) were able to produce as much honey as the control or package-only treatments (treatments 1,2 and 3) (Fig. 1), so that the higher income from nuclei sales resulted in greater total income. Treatment 5 (3 nuclei removed) did not produce as much honey as the other treatments, but still ranked among the top four treatments for total income due to the high nucleus income. Thus, package and/or nucleus production represents an additional source of income for beekeepers in the Lower Fraser Valley.

Beekeepers in $\mathrm{BC}$ are beginning to produce packages and nuclei and the indications are that this industry will continue to grow. In 1984, 983 packages and 1183 nuclei were produced and sold in $B C$ (McCutcheon, 1984b); by 1987, 2177 packages and 2394 nuclei were sold
(CAPA Proceedings, 1987), and 1988 figures will show a considerable growth for 1987. Winston et al. (1985) estimated that, at present colony densities, $\mathrm{BC}$ has the potential to produce 75520 spring packages each year, and increased colony density and a higher level of commercial beekeeping could elevate this figure. Continued and increased package and nucleus production, coupled with increased wintering and queen production, could result in a high degree of Canadian self-sufficiency within the next few years.

\section{ACKNOWLEDGMENTS}

We are grateful to $L$. Fergusson and $S$. Mitchell for field assistance. Financial support was provided by British Columbia Science Council and Natural Sciences and Engineering Research Council grants (M.L. Winston, principal investigator) and a Natural Sciences and Engineering Research Council Postgraduate Scholarship (to E.N. Punnett).

\footnotetext{
Résumé - Comparaison de la production de paquets d'abeilles et de nuclei à partir de colonies d'abeilles (Apis mellifica). Dans un rucher de l'Ouest du Canada on a prélevé en avril des paquets d'abeilles (essaims artificiels) et/ou des nuclei en diverses combinaisons, dans des colonies, afin de déterminer les conséquences biologiques de la production de paquets d'abeilles et/ou de nuclei sur ces colonies et d'en évaluer les retombées économiques. Pour former les paquets d'abeilles et les nuclei, on a retiré des colonies 2,7 kg d'abeilles ( 3 essaims de $0,9 \mathrm{~kg}$ ) et 12 rayons pleins, comportant couvain, miel, pollen et abeilles ( 4 rayons par nu-
} 
cleus), respectivement. D'avril et août on a relevé tous les 21 j environ les caractéristiques importantes des colonies : surfaces de couvain, de miel et de pollen, nombre de rayons couverts d'abeilles, poids total de la colonie et poids de miel récolté. Les valeurs moyennes par colonie ont été calculées.

Toutes les colonies utilisées pour la production d'abeilles (colonies testées) ont été d'un plus grand rapport que les colonies témoins. Le revenu moyen des témoins a été de 28,90 dollars canadiens par colonie, celui des colonies testées de 45,97 à 60,98 dollars canadiens par ruche. Par ailleurs, il n'y avait, à la fin de la saison, pour les caractéristiques suivies, aucune différence significative entre les colonies testées et les témoins.

Les résultats montrent donc que la production de paquets d'abeilles et/ou de nuclei est possible dans la basse Fraser Valley, en Colombie britannique, et que I'on peut ainsi créer un revenu supplémentaire pour les apiculteurs locaux et une nouvelle source d'abeilles pour les sélectionneurs.

\section{paquets d'abeilles - nuclei - impact économique - Canada}

\section{Zusammenfassung - Ein Vergleich der Paketbienen- und Ablegerproduktion} von Bienenvölkern. Auf einem Bienenstand in Westkanada wurden den Völkern im April in verschiedenen Kombinationen Paketbienen (Kunstschwärme) und/oder Ableger entnommen, um die biologischen Auswirkungen der Paketbienen- und Ablegerproduktion auf diese Völker und die ökonomischen Folgen zu erfassen. Für die Bienenpakete wurden bis zu 2,7 kg Bienen (3 Schwärme zu $0,9 \mathrm{~kg}$ ) pro Volk abgekehrt, für die Ableger bis zu 12 Vollwaben mit Brut, Honig, Pollen und Bienen ent- nommen ( 3 Ableger zu 4 Waben). Von April bis August wurden die wichtigsten Volksmerkmale im ungefähren 21-TageIntervall festgehalten. Die gemessenen Volksmerkmale waren: die Flächen von Brut, Honig und Pollen, mit Bienen besetzte Waben, Gesamtgewicht und Honigernte. Schließlich wurden die Mittelwerte pro Volk berechnet.

Alle zur Bienenproduktion eingesetzten Völker brachten einen höheren wirtschaftlichen Ertrag als die Kontrollvölker. Das mittlere Einkommen der Kontrollen war 28,90 kanadische Dollar pro Volk, aber die Paketbienen- und/oder Ablegerproduktion brachte 45,97 - 60,98 kanadische Dollar pro Volk. Außerdem gab es am Ende der Saison in praktisch allen protokollierten biologischen Merkmalen keinen signifikanten Unterschied zwischen den für Paketbienen- und/oder Ablegerproduktion benutzten Völkern und den Kontrollvölkern.

Diese Resultate zeigen, daß sowohl Paketbienen- wie Ablegerproduktion im unteren Fraser Valley in British Columbien möglich ist und daß auf diese Weise für die lokalen Bienenzüchter zusätzliche Einnahmen und für die Bienenzüchter weltweit eine neue Bienenquelle geschaffen werden könnte.

\section{Bienenproduktion - Paketbienen - Ableger - ökonomische Folgen}

\section{REFERENCES}

Anonymous (1983) Package bee production. British Columbia Ministry of Agriculture and Food. Clearbrook, BC 9p

Canadian Association of Professional Apiculturists (1987) Proceedings.

Farrar C.L. (1968) Productive management of honey-bee colonies. Am. Bee J. 108, 3-10 
McCutcheon D.M. (1984a) Annual Report 1984 Apiculture Program. British Columbia Ministry of Agriculture and Food, Clearbrook, BC

McCutcheon D.M. (1984b) Developing a queen and package bee production industry in $B C$ Can. Beekeeping 11, 81

Scott C.D. \& Winston M.L. (1985) Honeybee colony characteristics and profitability of pollination management systems. J. Apic. Res. 24, 4348

Statistics Canada (1984) Report to Canadian Honey Council in proceeding, CHC annual meeting.

Winston M.L. (1983) Research Review. British Columbia Honey Producers Association Newsletter, 4th Quarter, p. 7
Winston M.L. (1986) Can package bees and nuclei be produced commercially in British Columbia, Canada? Am. Bee J. 126, 36-38

Winston M.L. (1987) The Biology of the Honey Bee. Harvard University Press, Cambridge, MA Winston M.L. \& Fergusson L.A. (1985) The effect of worker loss on temporal caste structure in colonies of the honey bee (Apis mellifera L.). Can J. Zool. 63, 777-780

Winston M.L., Mitchell S.R. \& Punnett E.N. (1985) Feasibility of package honey bee (Hymenoptera: Apidae) production in southwestern British Columbia, Canada. J. Econ. Entomol. 78, 1037-1041

Winston M.L. \& Mitchell S.R. (1986) The timing of package honey bee (Hymenoptera: Apidae) production and use of two-queen management in southwestern British Columbia. J. Econ. Entomol. 79, 952-956 